\title{
A FACILIDADE DO APAGAMENTO DA HISTÓRIA: Orra, a rasura da voz feminina e a tragédia na loucura
}

Vanessa Cianconi

(UERJ)

RESUMO

A perversidade do século XIX vai além da simples definição do que é perverso no dicionário, a perversão de então estava no apagamento não somente da voz feminina, mas no apagamento do ato de ocultar os problemas da sociedade a serem discutidos na cena inglesa. Suprimir, esconder, tirar do palco as vozes que tinham o que dizer e eliminar o que poderia ser apresentado ao público a fim de faze-lo pensar. O teatro de Joanna Baillie tentou ser diferente enquanto argumentava que a mulher, isoladamente, não era suscetível ao medo supersticioso. Este artigo questiona o fato da peça Orra: A tragedy perfazer um caminho oposto ao defendido pela dramaturga em sua teoria da tragédia. No ato de enlouquecer ao final da peça, Orra, a mulher independente e forte de Baillie, se transforma na típica mulher fraca do século XIX e o apagamento acaba, por sua vez, sendo duplo, o da memória da dramaturga na história e o da sua personagem feminina.

PALAVRAS-CHAVE: Esquecimento; Joanna Baillie; teatro; século XIX 


\title{
EASILY ERASING HISTORY: Orra, the obliteration of the female voice and the tragedy in madness
}

\author{
ABSTRACT
}

Perversity in the $19^{\text {th }}$ century society goes beyond the simple definition of what is perverse in the dictionary; perversity lied on the oblivion not only of the feminine voice, but on the oblivion of the act of hiding society problems that could be discussed in the English scene. Suppress, hide, take off the stage voices, which had something to say, and erase what could have been presented to the public in order to make them think. Joanna Baillie's theater tried to be different while argued that the woman, alone, was not prone to a superstitious fear. This article questions the fact that the play Orra: A Tragedy treads a path opposite to what the playwright defended in her theory of the tragedy. When Orra, Baillie's independent and strong woman, goes mad at the end of the play, she turns herself into the standard $19^{\text {th }}$ century weak woman and the oblivion, in its turn, is a double oblivion: the playwright's memory in history and her female character.

KEY-WORDS: Oblivion; Joanna Baillie, theater; 19th century

"Where forms within the memory's ken are seen,

Forms faint or vivid, varying oft, that seem Like moving objects in a seried dream..."

Joanna Baillie 
O apagamento da voz feminina pode ser qualquer coisa menos um eufemismo. Desde tempos imemoriais a mulher é apagada, esquecida e colocada de lado no tecer da história. Não obstante, foi justamente esta mulher sem voz que desafiou todas as instituições normativas do passado e trouxe para o palco questões a serem levadas em conta e discutidas. Aphra Behn, por exemplo, uma das mulheres mais celebradas do século XVII, dramaturga, poeta e novelista, ganhou reputação primeiramente fundada nas suas peças "escandalosas", as quais ela jurava não teriam sido tão criticadas caso tivessem sido escritas por homens. Da Restauração à era Vitoriana, dramaturgas e tantas outras mulheres escritoras sobreviveram à crítica, à piada e até à sabotagem para se transformarem em presenças constantes no palco inglês. Curiosamente, muitas delas desapareceram não tão misteriosamente da história. Esta mesma mulher subversiva também foi um dos motivos através dos quais o teatro inglês fechou as suas portas por vários anos.

Vale lembrar que não somente as mulheres foram caladas na Inglaterra, a cena inglesa, desde sempre, passou por todo o tipo de censura; entre os anos de 1600 e 1660 os teatros permaneceram fechados por "proteção legal", "apagamento", "controle do estado". O teatro inglês trancou as suas portas de fato em 1642 quando o parlamento inglês decidiu fechar toda a cena inglesa. O objetivo era somente salvaguardar o público contra insurgências civis, no entanto, o ato acabou sendo ampliado pelos puritanos que associavam o teatro com as máscaras caríssimas usadas por Charles I na corte. Assim, se opor ao teatro era se opor ao absolutismo do rei. Além disso, os puritanos tinham medo de que o espetáculo corromperia a cabeça de seus devotos, afastando-os do caminho bíblico para a salvação. A bíblia também proibia o uso de costumes femininos por meninos: o teatro pré-1642 não aceitava mulheres no palco, logo, todos os papéis femininos eram feitos por rapazes transvestidos de meninas. Logo, o teatro era considerado imoral e ilegal pelos puritanos. Não muito tempo depois, o teatro inglês sofre uma nova onda de censuras no século XIX. Mesmo com a burguesia inglesa considerando o teatro como um lugar de glamour e onde atores conseguiam ganhar a vida honestamente, vários membros do parlamento apoiavam um projeto de lei para abolir o monopólio assegurado à duas companhias de teatro em 1830. O "Theater Regulation Act" [Ato de controle do teatro], quando aprovado em 1643, permitia qualquer companhia de teatro produzir todo o tipo de peça desde que mantivesse sólida a autoridade de Lorde Chamberlain podendo recusar licenciar per- 
formances públicas de peças que violassem as normas políticas e morais. A cena inglesa, então, pode-se afirmar, sempre sofreu com momentos de tensão durante os quais foram tiradas do palco peças que discutiam qualquer problema social ou político inglês. Desta forma, acredito não ser necessário esmiuçar o que aconteceu com a cena feminina de então.

É importante traçar algumas características da moralidade sexual vitoriana que moldava a sociedade daquele tempo. De acordo com Russell Goldfarb em seu livro Sexual Repression and Victorian Literature. a era vitoriana foi marcada por uma forte repressão sexual e qualquer tipo de expressão naquele sentido era intensamente sondado por agências de controle levando a própria palavra "vitoriana" ganhar uma conotação sexual única. A verdade, ainda segundo Goldfarb, é dizer que a sociedade vitoriana era obcecada em esconder o sexo e essa obsessão fez uma pressão extraordinária sobre a sociedade para satisfazer as suas próprias compulsões. A promiscuidade sexual era um pecado sem precedentes; mas também eram considerados pecado ler romances, ir ao teatro, ficar bêbado e deixar de rezar. Em 1843 o parlamento inglês aprovou um estatuto que regulava o que ia para o palco a fim de prevenir qualquer tipo de revolta nacional ou mal comportamento. Ironicamente, Dan H. Lawrence, em "Victorians unveiled", conta que somente em Londres, ao final do século XIX, havia um bordel em cada sessenta casas e uma meretriz para dezesseis mulheres. Fazendo um cálculo rápido, havia 6.000 bordéis em Londres e cerca de 80.000 prostitutas.

Nas notas introdutórias à sua peça Mrs. Warren Profession, George Bernard Shaw questiona o papel do teatro, para ele o teatro servia como um meio para um fim. A questão trazida por Shaw é, também, na contra mão da sociedade em que vivia,

... eles aprenderam que a autodefesa da senhora Warren e indiciação da sociedade é o que mais precisa ser dito, são as pessoas que mais me conhecem pessoalmente que me acusam, não por escrever essa peça, mas por jogar fora as minhas energias em "peças aprazíveis" para o divertimento de pessoas frívolas, quando posso criar sermões de palco fantásticos sobre os próprios trabalhos deles. (SHAW, 1994, p.4)

O que se discute aqui é a aplicabilidade desses "sermões de palco" de Shaw. O provável e real objetivo desses sermões é de ensinar o público alguma coisa, se não diretamente, alguma coisa ficaria a respeito da possibilidade de um novo papel da mulher na sociedade. Corroborando o anteriormente afirmado, para Shaw "a arte é o modo mais sutil, mais sedu- 
tor, e mais efetivo instrumento de propaganda no mundo" (SHAW, 1994, p.5). Toda a censura existente na Inglaterra vitoriana era para o dramaturgo "uma forma de evitar que as pessoas desafiassem concepções e instituições da época. Todo o progresso se inicia no desafio dessas concepções e na execução dessas instituições. Consequentemente a primeira condição para o progresso é a remoção da censura." (SHAW, 1994, p. 14) Ainda, Shaw, na mesma linha de pensamento que Brecht iria adotar anos depois, luta pelo teatro não com panfletos e sermões, mas com peças que faziam Londres levar para o teatro a consciência e o cérebro ao invés de deixa-los em casa com a bíblia. Provavelmente muito desafiador para a época.

Devido à muita censura e descaso, foi somente no início dos anos 2000, isto é, somente no início de século XXI, que uma dramaturga de Nova Iorque chamada Mallory Catlett, encontrou "sem querer" online, uma página da internet sobre duas dramaturgas inglesas: Susanna Centlivre e Elizabeth Inchbald; o curioso para ela era nunca ter ouvido coisa alguma sobre as duas. Em suas investigações, Catlett encontrou Gwynn MacDonald, diretora artística do Juggernaut Theater Company, também em Nova Iorque, e juntas resolveram recuperar o tempo perdido e trazer para a mesa de trabalho algumas das peças de dramaturgas esquecidas de séculos passados. Juggernaut, uma companhia fundada por ex-alunos de Julliard em 1994, programou uma série de vinte leituras, mesas-redondas, simpósios, uma vitrine para divulgação na Drama Book Shop, e até uma página na internet sob o título guarda-chuva de "The First 100 Years: The Professional Female Playwrights". A série de leituras e mesas-redondas olhou bem de perto para o trabalho de cinco dramaturgas dos séculos XVII e XVIII (algumas ainda pertenceram ao momento de transição entre os séculos XVIII e XIX), tais como: Aphra Behn (1640-89), Susanna Centlivre (1669-1723), Hannah Cowley (1743-1809), Elizabeth Inchbald (1753-1821) e Joanna Baillie (1762-1851). Segundo as diretoras do projeto, esse grupo foi selecionado por representar uma variedade de vozes e estilos que mostram o desenvolvimento profissional de dramaturgas naquele período.

A seleção dos textos clássicos chamou atenção de muitos estudiosos de teatro por nunca terem sido encenadas. Segundo MacDonald,

these are classical texts with no production history, so we don't have any preconceived ideas about what the actors should look like. We're hoping that these plays will increase the opportunities for nontraditional casting of classical works 
A ideia de Juggernaut era primeiramente de educar o público; "We want to introduce these artists and allow people into their worlds". Catlet afirmou que a empreitada pretendia deixar as pessoas pensarem por elas mesmas retirando política do cenário, ou seja, o material foi apresentado em sua forma crua e o público teria total participação nele. O objetivo era deixar o texto ser o centro do palco. Em um artigo do New York Times de 2003, as dramaturgas contaram que as peças escolhidas cobriam todos os tipos de campo possíveis, mas Joanna Baillie ocupou uma categoria somente dela: ela foi a dramaturga mais experimental de todas elas, uma "closet dramatist", muito mais lida do que representada. Baillie também escreveu mais comédias, geralmente sobre casais que deveriam estar juntos mas não estavam. Ao final da peça esses casais finalmente ficam juntos, a dramaturga lança mão de artifícios cômicos que geralmente se transformavam em convencionais para reunir esses casais novamente. Convenções são quebradas o tempo inteiro para tentar opor às restrições imputadas às mulheres o tempo todo impedindo-as de escolher por elas mesmas. Como dramaturga, Baillie questionava o por quê das mulheres não serem consideradas tão boas escritoras como os homens o eram, ou o por quê de seus trabalhos serem desvalorizados o tempo inteiro. Baillie concebeu um tipo de comédia humana no início de sua carreira que foi reproduzida em 27 peças. Delineando suas teorias no prefácio de $A$ Series of Plays: In Which It Is Attempted to Delineate the Stronger Passions of the Mind - Each Passion Being the Subject of a Tragedy and a Comedy, publicada em 1798, ela considerava a psicologia como condição si ne qua non para suas peças. Os personagens precisavam ser fortes e interessantes, exercendo suas paixões

with their full measure of opposition and struggle; for the chief antagonists they contend with must be the other passions and propensities of the heart, not outward circumstances and events.

Joanna Baillie é, dentro muitas outras coisas, uma dramaturga emergente do século XIX. Nascida em 1762 na Escócia, Baillie cresceu na Escócia rural com sua família, dona de uma imaginação fértil desde cedo atuava e odiava o isolamento que a escola e a leitura traziam. Entendeu desde sempre que para uma peça ser boa ela precisava de bons atores. Baillie era uma mulher muito além do seu tempo: apesar de cercada por homens inteligentes e poderosos, ela nunca se deixou dominar. Provavelmente por essa razão ela nunca se casou e, com bastante frequência, suas 
personagens rejeitavam o casamento e falavam abertamente sobre o mesmo como uma prisão. Apesar de muito ambiciosa, ela precisava aceitar o fato de que em um mundo masculino suas peças seriam mal produzidas e seu salario seria sempre muito mais baixo.

A play is certainly more perfect for being fitted for the stage as well as the closet, and why should not aim with all my strenght to make things as perfect as possible, however short I may fall on the Market? ... Don't you therefore find fault with me, or encrease the number of those who are for quietly setting me aside as a closet writer. I will still go on, having my drums and my trumpets, and my striking situations, and my side scenes and my back scenes, and all the rest of it in my mind, whislt I write, notwithstanding all that you can say to the contrary. (1804, de uma carta para o amigo William Sotheby)

Depois da mudança para Londres e do sucesso estrondoso em 1789 do primeiro volume de $A$ series of plays, no qual ela tenta delinear as paixões mais fortes da mente, cada paixão sendo o tema de uma tragédia e de uma comédia, Baillie publicou, em 1790, um livro pequeno chamado Poems, onde ela tenta descrever algumas formas de olhar a natureza. Segundo ela mesma, Poems foi composto após algumas tentativas infrutíferas de escrever peças para o teatro. Aparentemente, a primeira publicação não alcançou o sucesso esperado com a crítica especializada, todavia, Poems foi, sem dúvida, antecedente ao mais famoso Lyrical Ballads. Depois do sucesso dos dois volumes de A Series of Plays, em 1798 e 1802, Baillie começou a trabalhar em mais um volume de peças a ser lançado em 1805. Ao mesmo tempo ela estava trabalhando em sua peça The Family Legend, um drama sobre os highlands escocês. Curiosamente sua amizade com Sir Walter Scott rendeu a Legend uma produção de sucesso em 1810 além de ter sido fundamental em todas as suas tentativas de escrever poesia. Não se sabe ao certo quanto de revisão ou reescrita ele fez em seus poemas, mas Baillie comenta a respeito deles em uma carta (não se sabe para quem) em 1819. A editora Longman publicou duas edições de suas poesias em 1821. A partir de então Baillie continuou a publicar vários volumes de poesia pela mesma editora, inclusive serviu de organizadora para um volume com poemas de Walter Scott, Thomas Campbell, Samuel Rogers, William Wordsworth, dentre muitos outros. Suas cartas durante a edição do volume, encomendado pela própria Longman, mostrou seu bom senso para negócio, percepção crítica e edição, retornando poesias que não considerava boa o bastante para a publicação naquele volume. 
A partir de 1831, Baillie manteve uma produção extremamente frutífera, publicando volumes de poemas à peças teatrais. Uma coleção final chamada The Dramatical and Poetical Works of Joanna Baillie foi publicada em 1851 logo após a sua morte. O "livro monstro", como era chamado por ela, foi editado basicamente para seus herdeiros, mas também serviu como um movimento final para deixar a sua marca como mulher e poeta.

A vida de Baillie foi experimentada em um tempo de muitas mudanças sociais, políticas e intelectuais geradas por duas grandes revoluções em um mundo ainda muito patriarcal. Joanna, mesmo nesse mundo masculino, tentou repensar as ideias politicas do Iluminismo dentro dos gêneros narrativos e da representação dramática. Na introdução de suas Plays on the Passions de 1798, a dramaturga apelou para uma leitura revisionista da tragédia que reconstruiria o trágico, "paixões tirânicas" dos pequenos e esquecidos gestos do dia a dia. Um exemplo raro de teoria da literatura feminina daquele período, o Discourse, de Baillie, foi uma reinvindicação da crítica ideológica da tragédia para representar a natureza humana, a qual ela contava traçando as paixões humanas de sua genealogia da vida doméstica à torrencial, oficial visitação "trágica" na qual homens brancos irritadiços açoitam e humilham mulheres, crianças e finalmente a eles mesmos. Ao separar a tragédia da esfera doméstica da sociedade civil, Baillie também tentou transformar a já definida divisão de gêneros da sociedade civil em uma base a fim de criticar o mundo público, onde, na tragédia tradicional, sua "paixão trágica" parece ter sido feita a fim de ir além da história ao invés de se localizar em um mundo somente masculino e ligado à tirania do mundo inglês. Desta forma, a teoria da tragédia de Baillie foi menos uma tentativa de privatizar e domesticar a já controversa vida pública do que um esforço de repensar o modo de representação dramática como um discurso capaz de tornar explícita a política da vida pública no palco.

$\mathrm{Na}$ introdução do terceiro volume de sua Series of Plays, de 1812, Baillie afirma que aquele volume é composto inteiramente por representações diferentes de uma paixão; uma paixão que supostamente "is to be left adapted to dramatic purposes than any other - Fear" (iii). Segundo ela, ainda na mesma introdução, em uma tragédia o personagem principal não poderia ser incorporado por essa paixão, sem se tornar tão desgastado a ponto de ser incapaz de atrair a pena e interesse do espectador. A personagem principal dominada pelo medo, particularmente de um tipo de medo (o medo de fantasmas ou dos mortos que voltaram do além), 
é herdado e tão normal na nossa natureza a ponto de nunca poder ser apagado da mente, deixe o progresso da razão e da filosofia ser o que quiser ${ }^{1}$. Baillie ainda oferece insights psicológicos demonstrando conceitos novos de ilusão dramática. Em Discourse, ela argumenta que parte da tarefa que pertence à tragédia é:

unveiling the human mind under the dominion of those strong and fixed passions, which seemingly unprovoked by outward circumstances, will, from small beginnings brood within the breast, till all the better dispositions, all the fair gifts of nature are borne down before them, those passions which conceal themselves from the observation of men; which cannot unbosom themselves even to the dearest friend; and can, oftentimes, only give their fulness vent in the lonely desert, or in the darkness of midnight. (WU, 1998, p. 30-31)

Segundo Baillie, sua personagem principal foi criada sob a possibilidade do medo. Para ela, as pessoas com muita imaginação são as mais propensas a sentir medo do que não conseguem ver. A dramaturga criou Orra como uma moça alegre e divertida quando não está imediatamente sob a influência desse medo tão profundo, e até tira dessa inclinação supersticiosa um tipo de prazer, através do qual tenta nutrir e cultivar o inimigo que a destrói ${ }^{2}$.

É relevante notar que na introdução de suas peças Baillie desafia a crença tradicional de que as mulheres são mais inclinadas a sentirem medo do que os homens e explica que resolveu escrever uma segunda peça, com um personagem masculino, pois estava:

unwilling to appropriate this passion in a serious form to [her] own sex entirely, when the subjects of all the other passions hitherto delineated in [her Plays on the Passions] series are men.

\footnotetext{
${ }^{1}$ The principal character which is a woman, under the dominion of superstitious fear; and that particular species of it, (the fear of ghosts, or the returning dead,) which is so universal and inheritent in our nature, that it can never be eradicated from the mind, let the progress of reason or philosophy be what it may (BAILLIE, 1812 , p. iv).

${ }^{2}$ I have, therefore, made Orra a lively, cheerful, buoyant character, when not immediately under its influence; and even extracting from her superstitious propensity a kind of wild enjoyment, which tempts her to nourish and cultivate the enemy that destroys her. (BAILLIE, 1812, p. v)
} 
Ela rejeita a visão simplista de que a mulher é mais vulnerável do que o homem no "dominion of Superstitious Fear" e comenta que até o homem menos supersticioso do século XIX sucumbiria ao terror se estivesse sido hospedado em algum lugar onde um assassinato aconteceu e onde espíritos vinham para ficar perto de sua cama e puxar as cortinas no meio da noite. Ela reafirma que os medos de Orra "have nothing to do with apprehension of personal danger, and spring solely from a naturalhorror of supernatural intercourse" (ênfase minha). Apesar de Baillie entrar no essencialismo quando escreve não acreditar que as mulheres em relação à "perigos incertos" sejam tão corajosas quanto os homens, a experiência mostra que na forca as mulheres sempre agiram com mais determinação e calma do que seus companheiros masculinos. Ela sugere que a "paixão universal" do medo funciona de maneira muito similar em todos os indivíduos, independente de gênero. Em alguns casos, soldados na iminência de serem executados ficam totalmente horrorizados, enquanto mulheres, na mesma situação, se comportaram de forma calma.

A teoria de Baillie seria válida caso sua personagem feminina não fosse levada à loucura por causa do medo paralisador que sentia. Ao final da peça, Orra enlouquece por causa de sua imaginação fértil e perde a habilidade de conviver em sociedade. Apesar da recém-adquirida loucura de Orra liberá-la do possível matrimônio em si, ela a faz ajoelhar-se diante dos olhos poderosos do personagem masculino. É verdade que sua atitude em relação aos papéis dos gêneros na sociedade é um tanto quanto progressivo para a sociedade do século XIV, tempo no qual a peça é inserida, e até mesmo de seu tempo. Na posição de herdeira, Orra não quer casar para não perder o controle de seus bens e, claro, dela mesma. Ao conversar com dois amigos, um dos quais candidato a marido, ela comenta que o casamento a obrigaria a

consign [her]self

With all [her] lands and rights into the hands

Of some proud man, and say, 'Take all, I pray,

And do me in return the grace and favour

To be my master"' (BAILLIE, 1812, p. 22)

Ao invés de aceitar o enfadonho papel de esposa, Orra prefere permanecer solteira e presidir com Theobald de Falkenstein como co-habitante de Basle e manter, com suas aias, uma corte doméstica pura- 
mente feminina. No entanto, Orra estava ciente que manter um casamento igualitário não era possível e, naturalmente, escolheu permanecer solteira dada à relativa liberdade desejada. Ela conta a seu guardião e protetor, $\mathrm{o}$ Conde Hughobert, que era preferível casar com um homem morto a casar com o filho mal-educado dele. Neste momento de desobediência, ela desafia duas figuras paternas (seu próprio pai e seu guardião) e salvaguarda, até um certo ponto, um grau de autodeterminação. A fim de assustá-la e finalmente submetê-la à sua vontade, o Conde Hughobert e o não tão honesto Rudigere a confinam ao castelo Brunier, cuja fama é de assombrado pelo fantasma de um cavalheiro aparentemente assassinado no local. A conversa inicial entre Rudigere e Hughobert delineia o jogo sujo a ser colocado em prática pelos dois acólitos:

Rud. Hear me out.

Your ancient castle in the Suabian forest Hath, as too well you know, belonging to it; Or false or true, frightful reports. There hold her Strictly confined in somber banishment; And doubt but she will, ere long, full gladly Her freedom purchase at the price you name.

Hugh. On what pretense can I confide her there? Has she not favour shewn to Theobald, (...) I to her father swore I would protect her: I would fulfill his will.

Rud. And, in that will, her father did desire She might be match'd with this your only son; Therefore you're firmly bound all means to use That may the end attain (BAILLIE, 1812, 19-20)

Antes de seu confinamento, um empregado do castelo conta a Orra a lenda por trás do assassinato e esta conclui que é descendente do assino do cavalheiro. $\mathrm{O}$ medo que ela sentia sobe para um patamar diferente quando conclui que em suas veias corre o sangue de um assassino. Acredito que é nesse momento inicial em uma mente já muito fértil e infantil que Orra inicia um processo que a levaria à loucura. Algo a se considerar, pois vai de encontro à personalidade forte que parecia possuir. O diálogo abaixo exemplifica bem o caso: 
Cath. Since I must tell it, then, the story goes

That grim Count Willenberg, the ancestor

Of Hughobert and also of yourself,

From hatred or from envy, did decoy

A noble Knight, who hunted in the forest,

Well the Black Forest named, into his castle.

And there, within his chambre, murder'd him -

Or. Merciful Heaven! And in my veins there runs

A murderer's blood. Said'st thou not, murder'd him?

(...)

Cath. The neighbor'ing hinds oft hear the midnight yell

Of spectre-hounds, and see the spectre shapes

Of huntsmen on their fable steeds, with still

A nobler Hunter hiding in their van

To cheer the dsp'rate chace, by moonlight

Shwen,

When wanes its horn, in long October nights.

Or. This hath been often seen?

Cath. Aye, so they say.

But, as the story goes, on Michael's eve'

And on that night alone of all the year,

The Hunter-knight himself, having a horn

Thrice founded at the gates, the castle enters;

And, in the very chambre where he died,

Calls on his murd'rer, or in his default

Some true descendant of his hous, to loose

His spirit from its torment; for his body

Is laid i'the Earth unblefs'd, and none can tell

The spot of its interment.

Or. Call on some true descendant of his race!

It were to such a fearful interview.

But in that chambre, on that night alone - (BAILLIE, 1812, 71-72)

$\mathrm{Na}$ verdade, o crime teoricamente aconteceu no quarto no qual Rudigere a iria encarcerar.

É interessante notar o medo que Orra sentia vai contra a força supostamente imputada por Baillie às mulheres. Este medo a coloca justa- 
mente no centro do século XIX, e, na verdade, a faz assumir uma posição de fraqueza não delineada pela dramaturga na introdução de $A$ Series of Plays. Quando Theobald, o protetor de Orra, entra no castelo através de uma passagem subterrânea fantasiado do cavalheiro fantasma ela se assusta e perde a consciência. Aquela mulher que escolheu não casar para não perder o controle de seus bens, acaba por perder muito mais do que o controle de seus bens, ela perde o controle dela mesma ao preencher o requisito mais basal da mulher vitoriana: o da mulher louca.

O diálogo entre Catherine, Orra e Theobald serve para comprovar o que foi esmiuçado acima:

Or. Aye, for it is; day takes his daily turn,

Rifting between the gulphy dells of night

Like whiten'd billows on a gloomy sea.

Till glow-worms gleam, and stars peep thro' the dark,

And will-o'-the-wisp his dancing taper light,

They will not come again.

Hark, Hark! Aye, hark:

They are all there: I hear their hollow found

Full many a fathom down.

(...)

No, no! Athwart the wav'ring garish light,

Things move and seem to be, and yet are nothing.

El. My gentle Orra! Hast thou then forgot me?

Dost thou not know my voice?

Or. 'Tis like an old tune tom y ear return'd.

For there be those, who sit in cheerful halls

And breathe sweet air, and speak with pleasant founds;

And once I liv'd with such; some years gone by;

I wot not how long.

Or. Ha, ha! The witched air sings for thee bravely.

Hoot owls thro' mantling fog for mattin birds?

It lures not me. - I know thee well enough:

The bonés of murder'd men thy measure beat,

And fleshless heads nod to thee. - Off, I say!

Why are ye here? - That is the blessed sun. 


\section{(...)}

Or. Take it away! It was the swathed dead:

I know its clammy, chill, and bony touch.

Come not again; I'm strong and terrible now:

Mine eyes have look'd upon all dreadful things;

And when the Earth yeawn, and the hell-blast founds,

I'll 'bide the trooping of unearthly steps

With stiff-clench'd, terrible strength.

\section{(...)}

Theo. Give o'er, my Friends; you see it is in vain;

Her mind within itself holds a dark world

Of dismal fantasies and horrid forms!

Contend with her no more.

\section{$(\ldots)$}

Or. (...) A hideous burst hath been: the damn'd and holy, The living and the dead, together are

In horrid neighbourship. - 'Tis but thin vapour, Floating around thee, makes the wav'ring bound.

Poh! Blow it off, and see th'uncurtain'd reach.

See! From all points they come; Earth casts them up! In grave-clothes swarth'd are those but new in death; And there be some half boné, half cased in shreads Of thst which flesh hath been; and there be some With wicker'd ribs, thro' which the darkness scowls. Back, back! - They close upon us. - Oh the void Of hollow inball'd sockets staring grimly, And lipless jaws that move and clatter round us In mockery of speech! - Back, back, I say! Back, back! (BAILLIE, 1812, p. 92-100)

Em "The Rise of the Victorian Mad Moman", Showalter lembra que durante o século XIX vários hospitais ou casas de repouso surgiram, ao longo da Inglaterra, com os mais avançados tratamentos e terapias, para cuidar da mais nova "doença" feminina, o histerismo. A mulher histérica tomava conta do país e o maior culpado por isso, segundo os especialistas da época, era o ciclo menstrual feminino. O número de pacientes nesses hospitais aumentava exponencialmente à medida que a pobreza 
também aumentava no país. Coincidentemente, a pobreza era uma das causas morais da insanidade. Além do mais, doenças que eram “decorrentes" da pobreza também levavam essas mulheres à loucura e, consequentemente, ao hospício. Os psiquiatras vitorianos acreditavam que as mulheres eram mais suscetíveis à insanidade devido à instabilidade de seus órgãos sexuais que interferiam com o controle emocional e racional delas. As teorias da insanidade feminina eram todas produzidas a partir do ciclo reprodutivo feminino - puberdade, gravidez, menopausa - através do qual a mente se enfraqueceria e os sintomas da insanidade apareceriam. A conexão entre o ciclo reprodutivo feminino e o sistema nervoso, de acordo com os apontamentos de Showalter, levou ao que se chamou no século XIX de "insanidade reflexiva das mulheres". A autora ainda afirma que, segundo G. Fielding Blandford, a conexão entre o cérebro e o útero é facilmente vista pelo mais casual observador. Trocando em miúdos, a loucura feminina estava intimamente ligada ao que os médicos da época não conseguiam entender: o corpo feminino. Logo, a mulher insana do século XIX se tornou mais do que uma instituição, da literatura à vida pública, a "mulher louca do sótão" virou personagem recorrente e, a partir daí, a habitar não somente os hospitais, mas o imaginário popular.

Orra, infelizmente, não consegue fugir dessa instituição mesmo tendo sido concebida como uma mulher forte, decidida e independente por Baillie. Neste último momento, já no Ato $\mathrm{V}$, provavelmente, sua identidade de gênero perde sua força e a fronteira entre os vivos e os mortos se dissolve na sua mente como o cavalheiro morto, assim como ela, uma vítima da injustiça e da tirania, que parece se materializar para se vingar. Assim, ela se identifica com o assassino, com o seu antepassado e com a sua vítima, sendo ela mesma uma vítima em potencial. Orra perde completamente a ligação com a realidade e aqui se comprova o que os médicos do século XIX alegavam: "a hideous burst hath been: the damn'd and holy, The living and the dead, together are in horrid neighbourship" (BAILLIE, 1812, p. 100). Os mortos voltam, de alguma forma, para comungar com os vivos, e a loucura de Orra a tira da cena. Para Theobald:

Give o'er, my Friends; you see it is in vain;

Her mind within itself holds a dark world

Of dismal fantasies and horrid forms!

Contend with her no more. (BAILLIE, 1812, p. 99) 
Ao não se preocuparem mais com ela, Orra é automaticamente esquecida e sua posição de mulher na contramão da sociedade vitoriana é exposta e, de alguma forma, recolocada "no seu lugar", no lugar da mulher que vive em um "dark world, of dismal fanstasies and horrid forms" (BAILLIE, 1812, p. 99), no lugar da mulher que não merece uma posição de destaque na sociedade, no lugar da mulher apagada, eliminada da história. Orra, assim como Baillie, poderia ser esquecida, desta forma, a tentativa de delinear as fortes paixões da mente ficaram somente na tentativa ao sucumbir, em última instância, ao poder da sua própria mente.

\section{REFERÊNCIAS}

BAILLIE, Joanna. Series of Plays: In which it is attempted to delineate the Stronger Passions of the Mind. Vol. III. London: Longman, 1812

GOLDFARB, Russell. Sexual Repression and Victorian Literature. Bucknell University Press, 1975

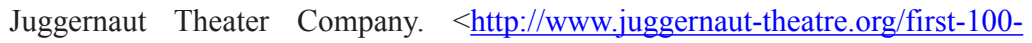
years-the-professional-female-playwright/>. Acessado em 29/09/2017

LAWRENCE, Dan H. “Victorians unvelied”. $<$ https://muse.jhu.edu/article/173220 $>$. Acessado em 04/09/2017

New York Times. $<$ www.nytimes.com $>$. Acessado em 30/09/2017

SHAW, George Bernard. "Mrs. Warren's Profession". In: Plays by

George Bernard Shaw. London: Signet Classics, 1994

SHOWALTER, Elaine. The Female Malady: Women, Madness and English Culture, 1830-1980. London: Virago, 1987

WU, Duncan. Companion to Romanticism. Blackwell, 1988.

ZARILLI, Phillip B. et all. Theater Histories. Ed. Gary Jay Williams. NY: Routledge, 2006.

Recebido em: 31/09/2018

Aceito em: 28/01/2019 